\title{
自己免疫疾患とエピゲノム修飾
}

\author{
藤尾圭志
}

\section{Autoimmune disease and epigenome regulation}

\author{
Keishi FuJIO \\ Department of Allergy and Rheumatology, Graduate School of Medicine, The University of Tokyo
}

(Accepted December 25, 2015)

\section{summary}

Epigenetic modifications play a central role in the cellular programming of gene expression. Two of the most characterized epigenetic modifications are DNA methylation and histone modification. Recent observation that a number of GWAS SNP for immunological diseases localize to immune enhancers suggests the importance of epigenetic modifications that control enhancer activity. Epigenome-wide analysis of DNA-methylation in systemic lupus erythematosus (SLE) and rheumatoid arthritis (RA) revealed differential DNA methylation in a number of disease-related gene pathways. With regard to histone mark, the requirement of millions of cells for established protocol prevents application to clinical samples. However, recent technical advances enable us to capture open chromatin in small amount of patient samples. As epigenetic modifications function as an integrator of environmental stimulation and the underlying genetic variant, detailed epigenetic analysis combined with genetic and environmental factors may facilitate the understanding of the progression of human immunological diseases.

Key words__ autoimmunity; rheumatoid arthritis; systemic lupus erythematosus; epigenome; histone modification

$$
\text { 抄 録 }
$$

遺伝子発現はエピゲノム修飾による転写因子の結合性の調節により制御されており，この調節機構は染色体を構 成するDNA およびヒストンの，メチル化やアセチル化による修飾から成り立っている。近年，自己免疫疾患の感 受性遺伝子多型の多くがエンハンサー領域に存在することが明らかとなり，この事実はエンハンサーの機能を制御 しているエピゲノムの重要性を示唆している。DNAメチル化に関しては，全身性エリテマトーデス（SLE）や関 節リウマチ（RA）の患者検体におけるエピゲノムワイドの解析が行われ，疾患発症に関わる重要な遺伝子の DNA メチル化が低下していることが明らかとなりつつある。ヒストン修飾については，解析に必要な細胞数の多さから これまであまり進んでいなかったが，最近の技術の進歩により少数細胞からの解析が可能となってきている。工ピ ゲノム修飾は遺伝素因と環境要因双方の影響が統合されるレベルであり，ヒト疾患におけるエピゲノム修飾を遺伝 素因と環境要因と関連付けつつ詳細に解析することで，ヒ卜疾患のメカニズムが明らかになることが期待される.

\section{1.はじめに}

自己免疫疾患を含む多くのヒト疾患は，その発症 に遺伝素因と環境要因の影響を受けると考えられて いる。遺伝素因に関しては近年のゲノムワイド解析 により疾患感受性遺伝子の解明が進んできたが, そ の中で免疫疾患の感受性多型はコーディング領域に はその $10 \%$ しか存在しないのに対し，60\%はエン ハンサー領域に存在することが分かってきだ） 。 してこのエンハンサーの機能を制御しているのはエ ピゲノム修飾であることから，遺伝素因の発現には

\footnotetext{
東京大学医学部アレルギー・リウマチ内科
}

エピゲノム制御が関与していることが明らかとなっ てきた。また共生微生物や共生微生物の代謝産物 が, 免疫細胞のエピゲノム修飾を介して免疫応答を 制御することも示されてきた2)。これらのことから， 遺伝素因と環境要因双方の影響はエピゲノム修飾の レベルで統合され，このエピゲノム修飾が以降の遺 伝子発現からの細胞機能を規定すると考えられる. 最近多くの自己免疫疾患においてもエピゲノムレベ ルの異常が報告されており, 病態のより深い理解に つながっている。本稿では各自己免疫疾患において 報告されているエピゲノムレベルの異常について概 説する. 


\section{2. エピゲノム修飾機構}

エピゲノム制御とはゲノムの DNA 配列の変化を 伴わない遺伝子発現調節のことであり, 染色体の構 造変化がその分子機構として知られている3 性双生児は遺伝子は同一だが, 細かい身体的特徵や 成人後に罹る疾患などはかなり異なっており，これ らはエピゲノム修飾の違いによるものと考えられる． 遺伝子の転写を制御するエピゲノム修飾には主に 3 つのメカニズムが考えられている。一つ目は以前か ら知られているDNA のメチル化による転写抑制で ある。二つめは最近急速に理解が進んでいる，ヒス トンタンパクの修飾である. 三つ目が small noncoding RNA による染色体構造調節であるが, 本稿では 自己免疫疾患に扔けるDNAメチル化とヒストンタ ンパクの修飾について概説する。

哺乳類染色体 DNA のシトシンの $5 \%$ はメチル基 が共有結合している。メチル化を受けるシトシンは $\mathrm{CpG}$ というパリンドロミックな配列のシトシンに 限定され, $\mathrm{CpG}$ 配列のシトシンの 7 割はメチル化 を受けている。 それ以外の並びの $\mathrm{CpA}, \mathrm{CpT}, \mathrm{CpC}$, のシトシンがメチル化されることはほとんどない。

この $\mathrm{CpG}$ 配列の新規のメチル化は DNA メチル化 酵素 (DNA methyltransferase, DNMT), DNMT3a と DNMT3bが行い, 複製の際のメチル化の維持を DNMT1 が担当する ${ }^{4,5)}$. メチル化された DNA に対 しては転写因子がその活性を発揮できなくなる。こ れはメチル化 DNA にメチル化 DNA 結合タンパク 質複合体が結合し，その複合体中のヒストンメチル 化酵素がヒストンをメチル化することで，ヒストン
を強く凝集した状態に保ち転写因子の結合を妨げる ためと考えられている（図 1 ）。興味深いことに, およそ $70 \%$ の遺伝子のプロモーター領域周辺に見 つかる $\mathrm{CpG}$ アイランドと名付けられた平均 $1 \mathrm{~kb} の$ 領域では $\mathrm{CpG}$ 配列は基本的に転写の有無によらず,

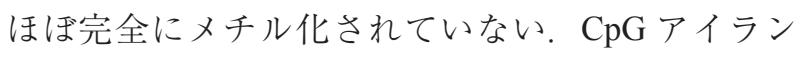
ドがどのようにしてメチル化を免れているのかは未 だ解明されていないが，その重要性が明らかとなり つつある脱メチル化酵素 Tet タンパク質が関与して いる可能性がある。

ヒストンの翻訳後修飾には, アセチル化, メチル 化，リン酸化などが知られている。そそれ゙れの修飾 は近傍遺伝子群の転写活性を示す良い指標となる。 これらの修飾の組合せは, 転写活性やクロマチン動 態に影響を及ぼすことが分かっており“ヒストン コード”と呼ばれる。一般に, ヒストンのアセチル 化により染色体が開いて転写は活性化すると捉えら れている（図 1 ）。従って脱アセチル化された染色 体領域は, 転写レベルでは不活性化された状態と考 えられる。一方, 様々なヒストンタンパク質の修飾 の中で, 染色体状態を規定する最も重要な修飾は メチル化であることが分かってきた。 メチル化は 修飾されるリシンやアルギニン残基によって意味 が異なり，ヒストン H3 のリシン 4 番目 (H3K4) や H3K36 のメチル化修飾は活性化を, 一方 H3K9 や H3K27 のメチル化修飾は抑制を引き起こすことが 知られている.H3K4 のメチル化ではモノメチル化 （H3K4me1）はエンハンサー領域に，トリメチル化 (H3K4me3) はプロモーター領域に存在し, 遺伝 子の転写を促進する。ヒストン修飾はその組合せ

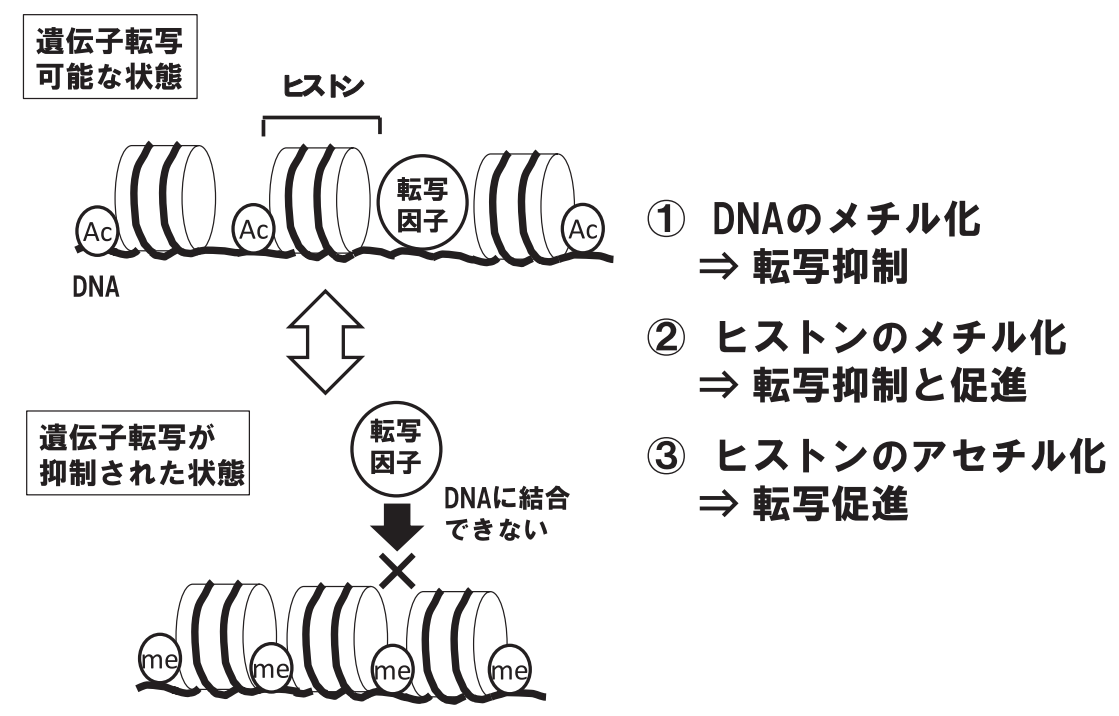

図 1 DNA やヒストンの修飾は DNA への転写因子の結合を制御する 
によって作用が決定されることもある。通常, H3K4me3 は転写活性が高い領域に, H3K27me3 は 転写活性が低い領域に多く存在するが，領域によっ ては相反する修飾が共存し “bivalent domain” と呼 ばれる。細胞によっては，遺伝子発現の ON/OFFを 迅速に切り替えるために, 必要な遺伝子では bivalent domain により待機状態にあると考えられる。

\section{3. 自己免疫疾患とエピゲノム修飾}

ここまで見てきたように，エピゲノム修飾は遺伝 子発現を制御する重要な機構である。エピゲノム修 飾は微生物や化学物質など環境要因の影響を受ける ことが知られている。何らかの環境要因によりエピ ゲノム修飾が変化すれば，それは遺伝子発現の変化 につながる，その結果，免疫応答において同じ方向 の変化が集積した場合には, 免疫応答に異常を来た す可能性がある。自己免疫疾患に扔いてエピゲノム の解析はまだ端緒についたばかりであるが，近年 の全身性エリテマトーデス（SLE）と関節リウマチ （RA）に関連する解析について述べてみたい.

\section{1）全身性エリテマトーデス}

全身性エリテマトーデス（SLE）は自己免疫疾患 の中で, 最もエピゲノムに関連する報告が多い.

SLEではアポトーシスを起こした細胞が重要な自己 抗原であるが, アポトーシス細胞の DNA は脱メチ ル化されている ${ }^{4)}$. 脱メチル化された DNA は微生 物のDNA と類似しているため免疫原性が高く, 自 己免疫応答を促進すると考えられている。プロカイ ンアミドは薬剤性ループスを惹起することが知られ ているが, このプロカインアミドは DNMTを阻害 することが報告され，DNA メチル化低下による何 らかの遺伝子発現の立進がSLEに関与しているこ とを示唆している ${ }^{6,7)}$.

SLE において特に $\mathrm{T}$ 細胞 $-\mathrm{B}$ 細胞相互作用を担 う遺伝子が脱メチル化されていることが報告されて いる. CD40L は T 細胞が抗体を産生する B 細胞を ヘルプする際に重要な共刺激分子である。CD40L 遺伝子はX染色体上に存在するため, 女性は潜在 的には男性の 2 倍の遺伝子を持っているが, 片方の $\mathrm{X}$ 染色体は通常不活性化されているため, CD40L の発現量は男性と同等に制御されている。しかし SLE では CD40L プロモーターは脱メチル化され, 女性の SLE 患者は男性の SLE 患者の 2 倍の CD40L 発現量となっている ${ }^{8)}$. この事実はSLE 発症の性差
と関連している可能性がある。CD70も B 細胞上の CD27 を刺激し，抗体産生を促進する共刺激分子で ある、薬剤性ループスを誘導するヒドララジンやプ ロカインアミドは CD70 遺伝子領域の脱メチル化を 誘導する。 SLE 患者の CD4 陽性 T 細胞では CD70 遺伝子領域が脱メチル化され，CD70の発現量が増 加している9).

近年はゲノムワイドの DNA メチル化解析により 多くの知見がもたらされつつある。 Javierreらは一 卵性双生児の一方のみがRA, SLEまたは皮膚筋炎 (Dermatomyositis: DM) を発症した各 30 例につい て, 807 か所の遺伝子のプロモーターに限定して, DNA メチレーションをアレイで解析した ${ }^{10)}$. RA と DMでは発症の有無でDNAメチレーションに一 定の差は認められなかったが, SLEでは発症して いる個体で 49 個の遺伝子のプロモーターの脱メチ ル化が認められた。これらの遺伝子にはIFNGR2, CSF3R（G-CSF receptor）などサイトカイン経路や 細胞増殖に関与する遺伝子が多く含まれていた。こ の報告はSLEが他の自己免疫疾患よりもエピゲノ ム修飾の影響を強く受けていることを示唆している。 Jeffries らは 2011 年にゲノムワイドの DNAメチル 化解析を報告した ${ }^{11)}$. 12 例の SLE 患者と 12 例の健 常人で, 27000 の $\mathrm{CpG}$ 領域を比較したところ，337 か所の $\mathrm{CpG}$ 領域がメチル化に差があり，うち 7 割 はメチル化が低下していた。個別の遺伝子では Matrix metalloproteinase 9 (MMP9) や CD9 の領域 のメチル化が低下しており, 遺伝子経路では葉酸合 成系の遺伝子に差が見られた，特に一部の遺伝子領 域のメチル化はSLE の疾患活動性と関連していた。

同じグループは 2013 年に 485,000 以上の $\mathrm{CpG}$ 領域 について, SLE 18 例と健常人 18 例の CD4 陽性 T 細 胞で解析し, 47 遺伝子の 86 か所の $\mathrm{CpG}$ 領域でメ チル化の差を認めたことを報告した ${ }^{12)}$. メチル化が 低下していた 35 遺伝子のうち IFI44Lを含む 21 遺 伝子は, I 型インターフェロンの下流で発現する遺 伝子であったが，メチル化の低下は疾患活動性とは 関連が無かった．Absher らはSLE 49 例，健常人 58 例の CD4 陽性 $\mathrm{T}$ 細胞, CD19 陽性 B 細胞, CD14 陽 性単球のゲノムワイドメチル化解析を報告してい る ${ }^{13)}$. メチル化の差がある $\mathrm{CpG}$ 領域は, B 細胞で 166 領域, 単球で 97 領域, $\mathrm{T}$ 細胞で 1033 領域で, 共通して I 型インターフェロン下流の遺伝子近傍の 領域を含んでいた。これらのメチル化の低下は, 活 動期だけでなく安定期にもみられた。このような 
SLEの免疫細胞におけるメチル化の低下は, I 型イ ンターフェロンへの反応性の充進に関与している可 能性があり，治療後の安定期にも残存していること から疾患の再燃とも関連しているのかもしれない （図 2）。このようなメチル化低下の機序は不明た が, Sunahori らはSLEのT細胞で発現が充進して いる protein phosphatase 2A（PP2Ac）をノックダウ ンすると, ERK 経路の活性化が上昇し, DNMT1 発 現の克進およびCD70 発現の抑制が誘導されること を報告した ${ }^{14)}$ 。どのようなシグナルが SLEにおけ るDNMT1の発現を制御しているのか，今後の解明 が待たれる。

SLEにおけるヒストン修飾に関してはまだ報告 が少ない. SLEでは IL-10の血中濃度が上昇してお り，IL-10 はヒトではB 細胞機能を克進させること から自己抗体産生に寄与している可能性がある。 Hedrich らは SLE の T 細胞の IL-10 産生が STAT3 に 依存しており，STAT3がヒストンアセチルトランス フェラーゼ p300の動員を介して IL-10 遺伝子のエ ピゲノムを修飾していることを報告した ${ }^{15)}$ ，今後ヒ ストン修飾に関する報告が期待される。

\section{2）関節リウマチ}

RA においては，おもに末梢血単核球全体の解析 でDNA メチル化全体の低下が報告されている。し かし DNA メチル化の低下と疾患活動性や, 臨床的 に有効な TNF 阻害療法との関連は確認されていな ( $^{16,17)}$ 。これらの解析はPBMC 全体を対象としてお り, 特定の細胞集団の変化は捉えられていない可能
性がある。従来の多くの報告は一部の候補遺伝子領 域に着目しており，CD40L 領域に関して SLE と同 様 RA でも女性においてのみ脱メチル化されている と報告された ${ }^{18)}$.

2013 年にLiu らは抗シトルリン化タンパク抗体 （anti-citrullinated protein antibody: ACPA）陽性のRA 患者 354 名と, コントロール 337 名でエピゲノムワ イドの DNA メチル化解析を行った ${ }^{19)}$. DNA サンプ ルは全血であるが，各サンプル内の $\mathrm{T}$ 細胞， $\mathrm{NK}$ 細 胞，B 細胞，単球および顆粒球の割合を補正して解 析された。 またRAの結果としての DNA メチル化 と原因としての DNA メチル化を区別するために, RA の脱メチル化領域の中でも遺伝子多型と関連す る部位に注目し，377 か所を同定した。興味深いこ とに遺伝子多型と RA の脱メチル化領域の関連の半 数は, $\mathrm{MHC}$ 遺伝子周囲の $5 \mathrm{Mb}$ の領域に集中してい た。ささらにこの $\mathrm{MHC}$ 領域に焦点を当てて遺伝子多 型との関連の強い脱メチル化領域を探索し，9 か所 の RAの脱メチル化領域を同定した。これらの RA の脱メチル化領域は RA において最も重要な感受性 遺伝子，HLA-DRB1 と有意に関連し，RAのリスク への関与が推測された。また RAの脱メチル化領域 は免疫細胞の中では, 単球において高い一致率を示 し, 単球において機能していることが示唆された。

RA の個々の細胞に関しては滑膜細胞において, DNA メチル化が検討されている，RA の関節の CD4 陽性 T 細胞は CXCR4を高発現しており, RAの 滑膜細胞（RASF）で産生が充進している CXCL12 により遊走していると考えられる ${ }^{20)}$. RASFではこ
染色体は閉じている

健常人

未治療
自己免庱
疾患患者

治療後 自己免㾥 疾患患者

染色体は開いている

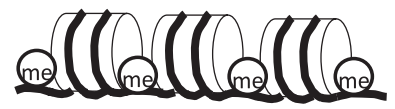

染色体は開いて転写因子が結合

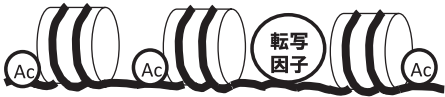

¿

mRNAは発現している
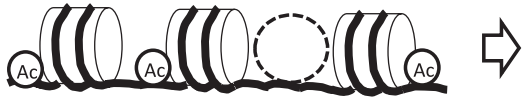

mRNAは発現していない

$\Rightarrow$ 䁒床的に寬解でも刺激があれば

容易に遺伝子が再発現
mRNAは秋現していない

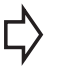

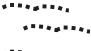

図 2 治療後の遺伝子発現の低下とエピゲノム状態の乘離の可能性 
の CXCL12 遺伝子が脱メチル化されていることが 報告されており，CXCL12 産生立進への関与が推測 される ${ }^{21)}$.2012 年に現産業医科大学の中野らは,

RASF と変形性関節症（OA）の OASF の比較では 初めてのエピゲノムワイド解析を行った。メチル化 に差があった 1859 の領域の中で $60 \%$ はメチル化が 六進しており， RAの免疫細胞における広範な脱义 チル化とは異なっていた。メチル化に差がある経路 は細胞遊走, 細胞接着, 細胞外マトリックス相互作 用などが示された ${ }^{22)}$. 2013 年には同様のエピゲノ ムワイドな解析により, RASF と OASFでは IL-6R や共刺激分子の CD26 の脱メチル化が異なっている ことが報告された23).

これらの報告は RA では DNA メチル化が変化し ていることを示しているが，どのようなメカニズム によりこの変化が惹起されているのであろうか？ 試験管内で IL-1, TNF- $\alpha$, TLR 刺激などを組み合わ せて刺激すると，DNA をメチル化する DNMT が抑 制され，特に IL-1 は DNMT 阻害剤と類似した効果 を示す ${ }^{24)}$ 。これらの結果は慢性炎症自体が DNA メ チル化修飾による RASF の表現型につながってい る可能性を示唆している。 Ai らは early RA 4 例と established RA 11 例の滑膜線維芽細胞のDNA メチ ル化を調べ，5469の遺伝子の $\mathrm{CpG}$ 領域のメチル化 に差があることを報告した ${ }^{25)}$. established RAでメ チル化が低下している遺伝子の経路として，Wnt/ $\beta$-catenin 経路，インテグリン経路，レチノイン酸 経路がピックアップされ，これらの経路が early RA と established RAの違いに関与している可能性が示 唆された。

RAにおけるヒストン修飾については報告が少 ないが, 岡山大学の川畑らは RASFでは OASFよ りヒストンデアセチラーゼ (histone deacetylase 1: HDAC1）活性が充進しており，RASFへの TNF- $\alpha$ 刺激によりヒストンデアセチラーゼ (histone deacetylase 1: HDAC1）発現が立進することを報告 した ${ }^{26)}$. HDAC1 は細胞の増殖と分化に関連してお り, p53 や p 21 などの細胞増殖や細胞分裂を抑制す る遺伝子の発現を低下させることが知られている.

RA に関しても今後ヒストン修飾に関する報告が期 待される。

\section{4. ヒストン修飾解析法の進歩}

これまでヒストン修飾の解析は, 特定のヒスト ン修飾部位を認識する抗体を用いて免疫沈降を行
うChIP シークエンスが中心であった。例えば抗 H3K4me1 抗体, 抗 H3K4me3 抗体, 抗 H3K27Ac 抗 体などを超音波で破砕した染色体に結合させ，沈降 してきた複合体に含まれる DNA 配列を次世代シー クエンスで解析することで，特定のヒストンマーク と関連する遺伝子領域の同定が可能である。この解 析はエピゲノムを解析する上で非常に有効であるが， 免疫沈降の抗体ごとの条件検討及び多くの細胞数が 必要であり，このことがヒト疾患におけるヒストン 修飾の解析があまり進まない理由であった，特に免 疫沈降のステップなどでのサンプルのロスが問題で, 近年は免疫沈降をせずに転写されやすい状態のオー プンクロマチンを同定する方法が開発されてきて いる ${ }^{27)}$. Formaldehyde-Assisted Isolation of Regulatory Elements (FAIRE) シークエンスでは，ホルムアル デヒドによりヒストン-DNA を架橋させ，フェノー ル・クロロフォルムにより架橋していないオープン クロマチンの DNAを抽出し, 次世代シークエンス を行う。この FAIRE シークエンスでは 10 万個程度 の細胞で解析が可能とされている。ささらに最近, より少ない細胞数でオープンクロマチンの解析が 可能な ATAC シークエンスが開発された ${ }^{28)}$. ATAC シークエンスでは, タンパクの結合していない裸の DNA 部位に選択的に挿入されるトランスポゾンを 使っている。核を抽出して，遺伝子シークエンスに 用いるプライマー配列を挿入したトランスポゾンを 作用させると，染色体の裸の DNA 部分にトランス ポゾンが飛び込み，ゲノム全領域の中で染色体の開 いた場所を標識することができる。この標識がシー クエンスプライマーになっており，この標識部位を シークエンスすることでオープンクロマチンが同定 できる。この ATACシークエンスでは 500- 5 万個 程度の細胞で解析が可能とされ, サンプル量に限界 のあるヒトサンプルの解析に道が開かれたと言える。

\section{5.おわりに}

エピゲノム修飾は遺伝子発現の主要な制御機構で あり，遺伝素因と環境要因が合流する生体応答レベ ルの 1 つである。自己免疫疾患におけるエピゲノム 解析は，まだ始まったばかりであるが，ヒト疾患に おけるエピゲノム修飾を遺伝素因と環境要因と関連 付けつつ詳細に解析することで, ヒト疾患のメカニ ズムが明らかになることが期待される。 


\section{文献}

1) Farh, K.K., et al.: Genetic and epigenetic fine mapping of causal autoimmune disease variants. Nature. 518: 337-343, 2015.

2) Furusawa, Y., et al.: Commensal microbe-derived butyrate induces the differentiation of colonic regulatory T cells. Nature. 504: 446-450, 2013.

3) Roadmap Epigenomics Consortium, et al.: Integrative analysis of 111 reference human epigenomes. Nature. 518: 317-330, 2015.

4) Jeffries, M.A., et al.: Autoimmune disease in the epigenetic era: how has epigenetics changed our understanding of disease and how can we expect the field to evolve? Expert Rev Clin Immunol. 11: 45-58, 2015.

5) Branco, M.R., et al.: Uncovering the role of 5hydroxymethylcytosine in the epigenome. Nat Rev Genet. 13: 7-13, 2011.

6) Scheinbart, L.S., et al.: Procainamide inhibits DNA methyltransferase in a human $\mathrm{T}$ cell line. The Journal of rheumatology. 18: 530-534, 1991.

7) Lee, B.H., et al.: Procainamide is a specific inhibitor of DNA methyltransferase 1. The Journal of biological chemistry. 280: 40749-40756, 2005.

8) Lu, Q., et al.: Demethylation of CD40LG on the inactive $\mathrm{X}$ in $\mathrm{T}$ cells from women with lupus. Journal of immunology. 179: 6352-6358, 2007.

9) Oelke, K., et al.: Overexpression of CD70 and overstimulation of $\mathrm{IgG}$ synthesis by lupus $\mathrm{T}$ cells and $\mathrm{T}$ cells treated with DNA methylation inhibitors. Arthritis and rheumatism. 50: 1850-1860, 2004.

10) Javierre, B.M., et al.: Changes in the pattern of DNA methylation associate with twin discordance in systemic lupus erythematosus. Genome research. 20: 170-179, 2010.

11) Jeffries, M.A., et al.: Genome-wide DNA methylation patterns in CD4 $+\mathrm{T}$ cells from patients with systemic lupus erythematosus. Epigenetics: official journal of the DNA Methylation Society. 6: 593-601, 2011.

12) Coit, P., et al.: Genome-wide DNA methylation study suggests epigenetic accessibility and transcriptional poising of interferon-regulated genes in naive CD4+ T cells from lupus patients. Journal of autoimmunity. 43: 78-84, 2013.

13) Genome-wide DNA methylation analysis of systemic lupus erythematosus reveals persistent hypomethylation of interferon genes and compositional changes to CD4+ T-cell populations. Absher
DM, et al. PLoS Genet. 9: e1003678, 2013.

14) Sunahori, K., et al.: The catalytic subunit of protein phosphatase 2A (PP2Ac) promotes DNA hypomethylation by suppressing the phosphorylated mitogen-activated protein kinase/extracellular signal-regulated kinase (ERK) kinase (MEK)/ phosphorylated ERK/DNMT1 protein pathway in T-cells from controls and systemic lupus erythematosus patients. The Journal of biological chemistry. 288: 21936-21944, 2013.

15) Stat3 promotes IL-10 expression in lupus $T$ cells through trans-activation and chromatin remodeling. Hedrich CM, et al. Proc Natl Acad Sci U S A. 111: 13457-13462, 2014.

16) Richardson, B., et al.: Evidence for impaired $T$ cell DNA methylation in systemic lupus erythematosus and rheumatoid arthritis. Arthritis and rheumatism. 33: 1665-1673, 1990.

17) Liu, C.C., et al.: Global DNA methylation, DNMT1, and MBD2 in patients with rheumatoid arthritis. Immunol Lett. 135: 96-99, 2011.

18) Liao, J., et al.: CD40L demethylation in CD4(+) $\mathrm{T}$ cells from women with rheumatoid arthritis. Clinical immunology. 145: 13-18, 2012.

19) Liu, Y., et al.: Epigenome-wide association data implicate DNA methylation as an intermediary of genetic risk in rheumatoid arthritis. Nature biotechnology. 31: 142-147, 2013.

20) Nanki, T., et al.: Stromal cell-derived factor-1-CXC chemokine receptor 4 interactions play a central role in $\mathrm{CD} 4+\mathrm{T}$ cell accumulation in rheumatoid arthritis synovium. J Immunol. 165: 6590-6598, 2000.

21) Karouzakis, E., et al.: DNA methylation regulates the expression of CXCL12 in rheumatoid arthritis synovial fibroblasts. Genes and immunity. 12: 643$652,2011$.

22) Nakano, K., et al.: DNA methylome signature in rheumatoid arthritis. Annals of the rheumatic diseases. 72: 110-117, 2013.

23) de la Rica, L., et al.: Identification of novel markers in rheumatoid arthritis through integrated analysis of DNA methylation and microRNA expression. Journal of autoimmunity. 41: 6-16, 2013.

24) Nakano, K., et al.: Regulation of DNA methylation in rheumatoid arthritis synoviocytes. Journal of immunology. 190: 1297-1303, 2013.

25) Ai, R., et al.: DNA Methylome Signature in Synoviocytes From Patients With Early Rheumatoid Arthritis Compared to Synoviocytes From Patients With Longstanding Rheumatoid Arthritis. Arthritis 
Rheumatol. 67: 1978-1980, 2015.

26) Kawabata, T., et al.: Increased activity and expression of histone deacetylase 1 in relation to tumor necrosis factor-alpha in synovial tissue of rheumatoid arthritis. Arthritis research \& therapy. 12: R133, 2010 .
27) Tsompana, M., et al.: Chromatin accessibility: a window into the genome. Epigenetics Chromatin. 7: 33, 2014.

28) Buenrostro, J.D., et al.: Transposition of native chromatin for fast and sensitive epigenomic profiling of open chromatin, DNA-binding proteins and nucleosome position. Nat Methods. 10: 12131218, 2013. 